\title{
IMPLEMENTASI STRATEGI PENINGKATAN KEPUASAN PASIEN DI RUMAH SAKIT GRANDMED LUBUK PAKAM
}

\section{Jon Piter Sinaga1, Harris Rambey ${ }^{2}$, Sri Melda Bangun ${ }^{3}$, Ika Nur Saputri ${ }^{3}$}

\author{
${ }^{1}$ Program Studi Ilmu Kesehatan Masyarakat, Institut Kesehatan Deli Husada Deli Tua \\ ${ }^{2}$ Program Studi Kesehatan Masyarakat, Institut Kesehatan Medistra Lubuk Pakam \\ ${ }^{3}$ Program Studi Kebidanan, Institut Kesehatan Medistra Lubuk Pakam \\ Jln. Sudirman No.38 LubukPakam, Kabupaten Deli Serdang, \\ Sumatera Utara - Indonesia \\ *email korespondensi author: jonpitersinaga@medistra.ac.id
}

DOI $10.35451 /$ jpk.v1i1.713

\begin{abstract}
Abstrak
Kepuasaan pasien merupakan suatu wujud hasil pelayanan yang diberikan oleh pihak rumah sakit terhadap pasien yang dapat diukur, dievaluasi untuk dimonitor, dikontrol dan ditingkatkan segala aspek yang berkaitan. Konsep kualitas pelayanan yang berkaitan dengan kepuasan pasien ditentukan oleh lima unsur yaitu daya tanggap, jaminan, berwujud, empati dan keandalan. Mutu pelayanan kesehatan menunjukkan tingkat kesempurnaan pelayanan kesehatan dalam menciptakan rasa kepuasan bagi setiap pasien pada setiap bentuk pelayanan yang telah didapatkan. Semakin sempurna kepuasan, semakin baik kualitas pelayanan kesehatan. Penelitian ini merupakan penelitian survei analitik dengan desain cross sectional. Pengumpulan data dilakukan dengan instrumen kuesioner yang diberikan kepada responden yang telah berobat dan akan pulang. Populasi dalam penelitian ini adalah seluruh pasien peserta Kartu Indonesia Sehat di ruang rawat inap RSUD Grandmed Lubuk Pakam, dengan jumlah sampel 80 orang. Pengumpulan data dilakukan dengan menggunakan kuesioner. Analisis data dilakukan secara bivariat dengan uji chi-square pada taraf kepercayaan $95 \%(a=0,05)$. Hasil penelitian menunjukkan bahwa terdapat hubungan antara dimensi berwujud kualitas pelayanan kesehatan (bukti langsung) dengan tingkat kepuasan pasien di ruang rawat inap dengan nilai $p$ value 0,050 dan ada hubungan antara kualitas pelayanan kesehatan pada dimensi jaminan (assurance) dan tingkat kepuasan pasien di ruang rawat inap dengan nilai $p$ value 0,046.
\end{abstract}

Kata kunci: Pelayanan kesehatan berkualitas, kepuasan pasien, tangible, assurance

\begin{abstract}
Patient satisfaction is a manifestation of the results of services provided by the hospital to patients that can be measured, evaluated to be monitored, controlled and improved in all related aspects. The concept of service quality related to patient satisfaction is determined by five elements, namely responsiveness, assurance, tangibles, empathy and reliability. The quality of health services shows the level of perfection of health services in creating a sense of satisfaction for each patient in every form of service that has been obtained. The more perfect the satisfaction, the better the quality of health services. This research is an analytic survey research with cross sectional design. Data was collected using a questionnaire instrument that was given to respondents who had received treatment and were going home. The population in this study were all patients participating in the Healthy Indonesia Card in the inpatient room of Grandmed Lubuk Pakam Hospital, with a sample of 80 people. Data collection was done by using a questionnaire. Data analysis was performed bivariately with chi-square test at 95\% confidence level $(a=0.05)$. The results showed that there was a relationship between the tangible dimensions of health
\end{abstract}


Received: 04 June 2021 :: Accepted: 30 June 2021 :: Published: 31 Desember 2021

service quality (direct evidence) with the level of patient satisfaction in the inpatient room with a $p$ value of 0.050 and there was a relationship between the quality of health services on the assurance dimension and the level of patient satisfaction in the inpatient room. with a $p$ value of 0.046 .

Keywords: Quality health services, patient satisfaction, tangible, assurance

\section{Pendahuluan}

Era globalisasi memberikan dampak arus kompetisi terjadi dalam pada semua program dalam bagian kesehatan jadi semakin baik. Setiap organisasi dalam pelayanan sistem kesehatan harus bisa meningkatkan mutu pelayanan yang berkesinambungan untuk mempertahankan bagaimana eksistensinya di dunia kesehatan (Sulistyo, 2016).

WHO menghimbau kepada setiap negara untuk melakukan pengambangan dalam jaminan kesehatan seluruh penduduknya (Universal Health Coverage), dengan adanya jaminan kesehatan diharapkan seluruh masyarakat di negara yang berkembang dalam jaminan kesehatan ini termasuk peserta jaminan kesehatan (WHO, 2010).

Kesehatan merupakan hal yang sangat di butuhkan dan bagian yang penting bagi manusia memperoleh kehidupan yang layak dengan cara memperoleh pelayanan kesehatan yang terkendali dalam biaya dan mutu pelayanan yang baik. Oleh sebab itu individu, keluarga maupun masyarakat berhak memperoleh dan mendapatkan kesehatannya serta pemerintah bertanggung jawab untuk meratakan semua sistem jaminan kesehatan (Hafid, 2014).

Masyarakat yang memiliki kemampuan dalam perwujudan keadaan yang sehat baik secara jasmani maupun secara rohani merupakan tujuan pembangunan bidang kesehatan di Indonesia.
Berbagai tindakan yang dilakukan pemerintah untuk melakukan sistem pembangunan dalam pelayanan kesehatan sehingga semua berjalan dengan baik dan lancar tanpa membedakan status ekonomi dan sosial harus diwujudkan untuk membantu pembangunan di program kesehatan (Depkes RI, 2008).

Konsep dalam pelayanan kerap dikaitkan dengan meningkatkan jumlah kepuasan pasien yang diukur pada assurance, tangible, empathy dan reliability, dan responsiveness. tingkat pengguna kepuasan merupakan suatu keadaan yang dapat dirasakan dalam diri seseorang sehingga membuat orang tersebut merasa dihargai (Pohan, 2007).

Jika pelayanan kesehatan bisa memuaskan pasien maka menjadi indicator penting dlaam mutu pelayanan kesehatan. Dikatakan kepuasaan jika kualitas jasa pelayanan yang diberikan sesuai dengan keinginan, kebutuhan, dan harapan pengguna. Rumah sakit merupakan bagian dari organisasi social dan medis yang memiliki fungsi untuk memberikan pelayanan kesehatan masyarakat berbasis kuratif dan rehabilitative, sebagai tempat latihan tenaga kesehatan serta penelitian biososial. Setiap fasilitas pelyanan memiliki kewajiban untuk mempertanggungjawabkan pelayanan yang telah diberikan yakni dengan membuat satu sistem informasi kesehatan. Untuk informasi kesehatan yang ada dibutuhkan peran profesi rekam medis yang bertugas mulai dari data awal pasien sampai dengan informasi kesehatan (Budi, 2011). 
Received: 04 June 2021 :: Accepted: 30 June 2021 :: Published: 31 Desember 2021

Instalasi Rawat Jalan Rumah Sakit Grandmed terdiri dari Klinik spesialis dan sub spessialis dengan fasilitas penunjang yang cukup memadai. Kegiatan pekerja yang dilaksanakan mulai dari awal pendfatran sampai ke tahap pelayanan membutuhkan waktu yang lama. Berdasarkan data awal yang di peroleh dari wawancara kepada pasien JKN menyebutkan bahwa masih ditemukan pasien sebagai pengguna JN masih kurang diperhatikan khsusunya ketika mereka ingin mendaftarkan diri untuk mendapatkan perobatan. Berdasarkan keluhan pasien tersebut bisa digolongkan ke aspek kualitas pelayanan kesehatan meliputi keandalan, bukti fisik, keyakinan, responsive dan empati.

\section{Metode}

Pelaksanaan dalam kegiatan pengabdian masyarakat berupa pengukuran kualitas pelayanan kesehatan sebagai implementasi strategi peningkatan pasien. Pengukuran kepuasan pasien dilakukan melalui pengisian lembar kuesioner yang merupakan instrumen pengukuran kepuasan pasien rawat inap, oleh pasien yang akan pulang. Lembar kuesioner ini terdiri dari kumpulan pernyataan yang meliputi 5 dimensi kepuasan yang merupakan indikator utama yang memengaruhi kualitas layanan menurut konsep service quality ServQual yaitu bukti langsung (Tangibles), kendala (Reliability), daya tanggap, jaminan) dan empati (Parasuraman, 1985).

Komponen dimensi Tangibles meliputi penilaian pelanggan terhadap segala sesuatu yang bisa dilihat dan dirasakan langsung seperti fasilitas fisik, peralatan medis, penampilan pekerja serta tampilan makanan yang disajikan. Komponen dimensi Reliability meliputi penilaian pelanggan terhadap kehandalan

institusi

dalam

menyediakan layanan yang diperoleh secara akurat dan terpercaya. Komponen dimensi Responsiveness meliputi penilaian pelanggan terhadap kecepatan layanan yang diberikan pihak rumah sakit. Komponen dimensi Assurance meliputi penilaian pelanggan terhadap pengetahuan dan kesopanan pekerja serta kemampuan yang meyakinkan dan terpercaya dalam memberikan suatu layanan kesehatan. Komponen dimensi Empathy meliputi perhatian secara individual terhadap pasien (Daniel, 2010).

\section{Hasil dan Pembahasan}

Pengukuran kepuasaan hasil implementasi strategi yang telah dilakukan dengan karakteristik responden yang berpartisipasi dapat dilihat dalam berikut ini.

Tabel 1. Distribusi Karakteristik Pasien

\begin{tabular}{lcc}
\hline \multicolumn{1}{c}{ Variabel } & F & \% \\
\hline Umur & & \\
$<20$ tahun & 15 & 17,9 \\
$20-35$ tahun & 24 & 28,6 \\
$>35$ tahun & 45 & 53,6 \\
\hline Total & $\mathbf{8 4}$ & $\mathbf{1 0 0 , 0}$ \\
\hline Jenis Kelamin & & \\
$\quad$ Laki-laki & 38 & 45,2 \\
Perempuan & 46 & 54,8 \\
\hline Total & $\mathbf{8 4}$ & $\mathbf{1 0 0 , 0}$ \\
\hline Pendidikan & & \\
Terakhir & & \\
SD & 3 & 3,6 \\
SMP & 12 & 14,3 \\
SMA & 43 & 51,2 \\
D3/S1 & 20 & 23,8 \\
S2 & 6 & 7,1 \\
\hline Total & $\mathbf{8 4}$ & $\mathbf{1 0 0 , 0}$ \\
\hline Pekerjaan & & \\
Wiraswasta & 12 & 14,3 \\
IRT & 33 & 39,3 \\
Petani & 11 & 13,1 \\
PNS & 3 & 3,6 \\
Tidak Bekerja & 25 & 29,8 \\
\hline Total & $\mathbf{8 4}$ & $\mathbf{1 0 0 , 0}$ \\
\hline & & \\
\hline & &
\end{tabular}


Received: 04 June 2021 :: Accepted: 30 June 2021 :: Published: 31 Desember 2021

Tabel 1 menyebutkan bahwa jumlah responden di peroleh mayoritas umur $>35$ tahun sebanyak 45 orang $(53,6 \%)$, pada jenis kelamin perempuan ada 46 orang (54,8\%), pendidikan terakhir SMA sebanyak 43 orang $(51,2 \%)$, dan pekerjaan IRT sebanyak 33 orang $(39,3 \%)$.

Tabel 2. Distribusi Dimensi Kepuasaan Pasien

\begin{tabular}{|c|c|c|}
\hline Variabel & $\mathrm{F}$ & $\%$ \\
\hline \multicolumn{3}{|l|}{ Tangible } \\
\hline Baik & 32 & 40,0 \\
\hline Cukup & 46 & 57,5 \\
\hline Kurang & 2 & 2,5 \\
\hline Total & 80 & 100,0 \\
\hline \multicolumn{3}{|l|}{ Assurance } \\
\hline Baik & 28 & 35,0 \\
\hline Cukup & 50 & 62,5 \\
\hline Kurang & 2 & 2,5 \\
\hline Total & 80 & 100,0 \\
\hline \multicolumn{3}{|l|}{ Reliability } \\
\hline Baik & 28 & 35,0 \\
\hline Cukup & 50 & 62,5 \\
\hline Kurang & 2 & 2,5 \\
\hline Total & 80 & 100,0 \\
\hline \multicolumn{3}{|l|}{ Empathy } \\
\hline Baik & 31 & 38,8 \\
\hline Cukup & 47 & 58,8 \\
\hline Kurang & 2 & 2,5 \\
\hline Total & 80 & 100,0 \\
\hline \multicolumn{3}{|c|}{ Responsiveness } \\
\hline Baik & 9 & 11,2 \\
\hline Cukup & 67 & 83,8 \\
\hline Kurang & 4 & 5,0 \\
\hline Total & 80 & 100,0 \\
\hline
\end{tabular}

Tabel 2 menunjukkan dimensi kepuasaan pasien diukur dari lima aspek yaitu: tangible, assurance, reliability, empathy dan responsiveness. Mayoritas pasien berdasarkan tangible (bukti nyata) kategori cukup berjumlah 46 orang $(57,5 \%)$, assurance (jaminan) kategori cukup berjumlah 50 orang $(62,5 \%)$, reliability (dapat dipercaya) kategori cukup berjumlah 50 orang $(62,5 \%)$, empathy (empati) kategori cukup berjumlah 47 orang $(58,8 \%)$ dan responsiveness (daya tanggap) kategori cukup berjumlah 67 orang $(83,8 \%)$.

Dalam pemenuhan kualiatas layanan kesehatan merupakan kunci utama untuk memperolah kepuasan bagi para pengguna jaminan kesehatan sesuai dengan peruntukannya, suatu layanan yang berkualitas dapat memberikan jasa pelayanan kesehatan yang benar-benar sesuai dengan kebutuhan pasien dan menunjuk pada tingkat kesempurnaan pelayanan. Makin sempurna pelayanan kesehatan yang diberikan tersebut maka makin baik pula mutu pelayanan kesehatan. Selama masa perawatan, pasien merasakan atau menerima pelayanan kesehatan dari pihak rumah sakit mulai dari pelayanan dokter, perawat, pelayanan administrasi dan penerimaan fasilitas fisik, maka selama itu pula pasien dapat merasakan atau menerima pelayanan kesehatan dari pihak rumah sakit mulai dari pelayanan pelayanan dokter, perawat, pelayanan administrasi dan penerimaan fasilitas fisik, maka selama itu pula pasien dapat merasakan dan memberikan penilaian mengenai kualitas pelayanan kesehatan yang mereka peroleh. Kualitas pelayanan kesehatan diukur dengan lima aspek yaitu: Tangible, Assurance, Reliability, Empathy, Responsiveness.

Tangible (bukti langsung) ialah suatu usaha atau kemampuan perusahaan dalam membuktikan eksistensinya kepada semua pihak yang terkait. Penampilan dan gaya seseorang maupun esensi kantor juga akan membutktikan bahwa mereka memiliki nilai yang lebih untuk dapat mensejahterakan para karyawannya seperti mempasilitasi dalam memproleh pelayanan kesehatan seperti JKN di tempat mereka bekerja. 
Received: 04 June 2021 :: Accepted: 30 June 2021 :: Published: 31 Desember 2021

Penelitian Winda tahun 2013 hasil penelitian menunjukkan bahwa bukti langsung pelayanan kesehatan berhubungan dengan kepuasan pasien pengguna askes sosial pada pelayanan rawat inap. Beberapa hal yang mendukung bukti langsung pelayanan yang baik adalah kondisi ruang perawatan yang bersih dan didukung tersedianya fasilitas penunjang diruang perawatan seperti kamar mandi yang bersih, kenyamanan ruang perawatan dan penampilan petugas kesehatan yang rapi dan bersih. Assurance menggambarkan pengetahuan dan keramahan staf rumah sakit yang dapat menimbulkan kepercayaan dari pasien terhadap rumah sakit. Pasien dalam memberikan penilaian sesuai dengan apa yang diterima mereka dalam hal pengetahuan, kemampuan, keramahan tenaga medis dalam menangani masalah kesehatan mereka dan kemampuan pihak rumah sakit dalam menumbuhkan kepercayaan atas pelayanan kesehatan yang diberikan dalam diri pasien.

Dalam pelayanan kesehatan yang bermutu sangat mempengaruhi kepuasan pasien di poliklinik, selain itu faktor yang dapat mempengaruhi tingkat kepuasan pasien adalah waktu tunggu tellau lama, jam berobat di batasi, sikap pengawai yang tidak ramah, pengalaman pegawai yang masih sedikit dan ketidak mampuan dalam melakukan komunikasi yang baik. Hal ini sangat perlu diperhatikan sehingga tidak ditemukan lagi tingkat pelayanan kesehatan yang tidak puas.

\section{Kesimpulan}

Dengan melakukan pelayanan kesehatan yang baik serta memperhatikan tingkat kebutuhan pasien, sangat perlu menciptakan suasana dan hubungan yang baik antar sesama pengguna jaminan kesehatan, sehingga pelyanan yang berkualitas dapat diterapkan dan di rasakan oleh semua kalangan.

\section{Ucapan Terima Kasih}

\section{Ucapan terima}

kasih disampaikan kepada Lembaga Penelitian dan Pengabdian Masyarakat Institut Kesehatan Medistra Lubuk Pakam, Kepala Unit Kerjasama Pendidikan dan Penelitian Rumah Sakit Grandmed Lubuk Pakam dan para Bapak/Ibu peserta edukasi.

\section{Daftar Pustaka}

Alamsyah, Dedi. 2007. Manajemen Pelayanan Kesehatan. Nuha Medika, Yogyakarta

Azwar, 2007. Administrasi Kesehatan Masyarakat. Bina Rupa Jakarta

Bata. Winda yuristi. 2013. Hubungan Kualitas Pelayanan Kesehatan Dengan Kepuasan Pasien Pengguna Akses Sosial Pada Pelayanan Rawat Inap di RSUD Laki Padada Kabupaten Tanah Roja. Jurnal. Universitas Hasanuddin Makassar

Fitriyani, 2016. Kebijakan Pemerintah Tentang Program Kartu Sakti Dalam Perspektif Siyasah (Studi Kasus Desa Taman Martani Kecamatan Kalasan Kbupaten Sleman, Skripsi. Universitas Islam Negeri Sunan Kalijaga. Yogyakarta

Machfoedz, Ircham. 2010. Metode Penelitian Kuantitatif \& Kualitatif Bidang Kesehatan, Keperawatan, Kebidanan, Kedokteran. Yogyakarta: Fitramaya

Notoadmodjo, 2010. Metodologi Penelitian Kesehatan. Jakarta: Rineka Cipta

Saputro, Dwi Agus. 2015. Hubungan Kualitas Pelayanan Kesehatan Dengan Kepuasan Pasien Rawat Jalan Tanggungan BPJS di RS Bethesda Yogyakarta, Skripsi Universitas Muhammadiyah Surakarta 